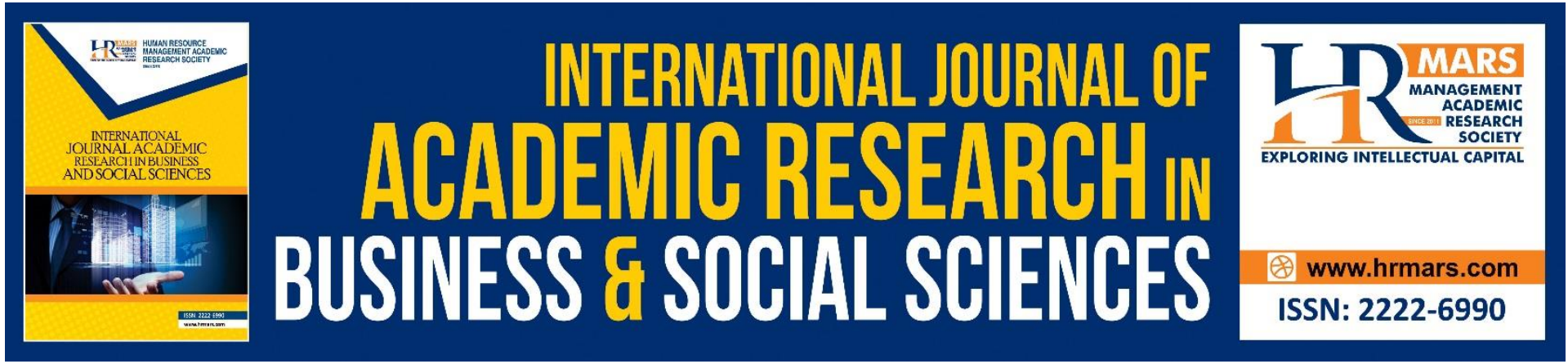

\title{
A Case Study on the Impact of Using Collaborative Writing and Editing among Tertiary-Level Students in a Google Classroom
}

\section{Siew Fong Lin}

To Link this Article: http://dx.doi.org/10.6007/IJARBSS/v11-i7/10543

DOI:10.6007/IJARBSS/v11-i7/10543

Received: 19 May 2021, Revised: 20 June 2021, Accepted: 09 July 2021

Published Online: 29 July 2021

In-Text Citation: (Lin, 2021)

To Cite this Article: Lin, S. F. (2021). A Case Study on the Impact of Using Collaborative Writing and Editing among Tertiary-Level Students in a Google Classroom. International Journal of Academic Research in Business and Social Sciences, 11(7), 881-891.

Copyright: () 2021 The Author(s)

Published by Human Resource Management Academic Research Society (www.hrmars.com)

This article is published under the Creative Commons Attribution (CC BY 4.0) license. Anyone may reproduce, distribute, translate and create derivative works of this article (for both commercial and non-commercial purposes), subject to full attribution to the original publication and authors. The full terms of this license may be seen at: http://creativecommons.org/licences/by/4.0/legalcode

Vol. 11, No. 7, 2021, Pg. 881 - 891

Full Terms \& Conditions of access and use can be found at http://hrmars.com/index.php/pages/detail/publication-ethics 


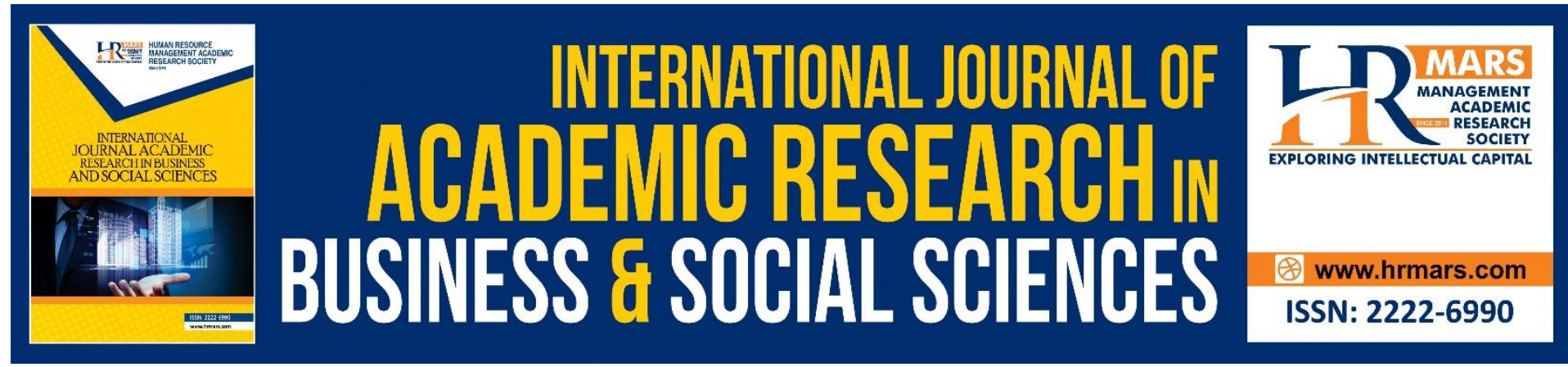

\title{
A Case Study on the Impact of Using Collaborative Writing and Editing among Tertiary-Level Students in a Google Classroom
}

\author{
Siew Fong Lin \\ Tunku Abdul Rahman University College P.O Box 1097950932 Kuala Lumpur Malaysia \\ Email: linsf@tarc.edu.my
}

\begin{abstract}
Investigation on the use of both collaborative writing and Google Classroom during group tasks among Malaysian students from a degree in Graphic Design programme is the objective of this study. The participants selected had completed a product-centred English course which focused on communication at the workplace, academic writing and reading for academic purposes prior to data collection. Group-writing tasks in the form of producing a memorandum, a letter of complaint and an argumentative essay were performed by four case study groups in this study. Research instruments used to obtain data of the student collaboration were interviews, diary entries and observations. Consequently, benefits on task performance derived from student collaboration and the impact of using collaborative writing and editing in a Google Classroom were obtained. The critical incidents observed in the study were an increase of motivation in performing tasks and a decrease of anxiety in receiving feedback from peers. In addition, recommendations on improving collaborative writing and editing ranged from setting a shorter deadline for collaborative work, providing clear roles to participants and providing appropriate guidance in providing feedback. It could be concluded that Google Classroom is an effective application in promoting learning among tertiary-level students when its use is refined.
\end{abstract}

Keywords: Google Classroom, Collaborative Editing, Critical Incidents

Introduction

Ede and Lunsford (1990) whose research focus is on sociocultural stance in second language acquisition state that the process of collaborative writing occurs when two writers or more than two writers compose together. Collaboration enhances quality of writing (Storch, 2005); promotes knowledge building (So, Seah \& Toh-Heng, 2010); enables learners to be competent in the modern world (Jones, 2007); encourages reflection on language use (Swain, 2000); creates a sense of audience (Sun \& Chang, 2012) and provides opportunities to socialise in discourse communities (Yang, 2014). Therefore, collaborative work is commonly used in many academic settings and workplaces.

There are studies which have been conducted in the areas of collaborative editing and peer feedback. A study conducted by Hafner and Yu (2020) examined the impact of teacher 
and peer feedback on collaborative writing. It was discovered that the feedback when mediated by track changes and functions in Microsoft Word pertaining to providing comments could become a mode of socialisation. Another study carried out by Liao (2020) compared language-related episodes among native and non-native speakers. It was found that native speakers benefited in terms of organisation and ideas while non-native speakers improved on their vocabulary and expressions with power relationship influencing learner discourse.

Technical advancements promote the always-connected working style and consequently, collaborative text editing which makes remote collaboration possible can be carried out with the use of Google Docs, Etherpad and Overleaf (Kumar et al, 2020). Yim and Warshauer (2017) further concur that the increase use of softwares such as Wikis and Google Docs in second language classroom has resulted in heighten interest in collaborative writing. In addition, with the spread of the present worldwide pandemic, Covid-19, face-to-face lessons in traditional classrooms have been replaced with online classes. The e-learning tools or Learning Management System (LMS) used include Google Meet, Moodle, Edmodo, Schoology and Google Classroom.

Jakkaew and Hemrungrote (2017) are of the opinion that Google Classroom is one of the popular LMS used. Google Classroom is an educational application designed by Google Inc. to ease forming, disseminating and organising paperless learner assignments (Khalil, 2018). Furthermore, Google Classroom enables teachers to conduct teaching and learning successfully (Ela \& Tatik, 2020) and to grade student assignments simultaneously (Iftakhar, 2016).

Research findings from studies conducted on the use of Google Classroom have revealed benefits gained by both teacher and learner. They range from increasing students' interest (Aulia, Afrianto \& Mahdum, 2020; Jeya \& Brandford, 2019); encouraging student participation (Heggart \& Yoo, 2018); motivating students (Ramadhani et al., 2019) and having an improvement in writing (Ela \& Tatik, 2020).

However, success from the use of student collaboration and Google Classroom in teaching and learning is not ensured. Challenges faced during collaboration could be having different levels of commitment (Hernandez, 2012) and neglecting low-proficiency learners in groups (Bennett \& Cass, 1988). It was found that the use of using Google Classroom, too, is not significantly effective in teaching of English (Cantika \& Rezki, 2020). There is also insufficient study on the effects of online collaboration on the writing products (Wang \& Vásquez, 2012). Furthermore, there is much research conducted on use of Google Classroom as a facilitation tool but not on its effects on teaching methodologies (Azhar \& lqbal, 2018).

There is a need to conduct more research on the impact of using collaborative work and Google Classroom among learners. Therefore, the research questions for this study are:

1. What critical incidents are observed when collaborative writing and editing are used in a Google Classroom?

2. What are recommendations of improving collaborative writing and editing in a Google Classroom? 


\section{Theoretical Background}

Learners gain many benefits when they are involved in verbal exchanges with one another. This is supported by Dillenbourg et. al (2009), who highlights the major role of interactions in improving cognitive skills. Vygotsky (1986) elaborates that knowledge building in a learner does not exist in isolation but in a social context.

When learners interact with one another, they will build their knowledge by exchanging information and refining their thoughts. They need reasoning skills to help them filter the input they receive from their counterparts. Instructors may experience difficulty in teaching learners these skills but they can improve by receiving scaffolding from their peers (Waggoner et al., 1995).

Learners can increase their comprehension of information through co-construction of knowledge. This is made possible through differences in the ways of thinking which result in socio-cognitive conflicts. Learners' prior knowledge is challenged through the dissimilarities of views presented.

The differences in thinking simultaneously promote learning for the learners' prior knowledge is reshaped and refined. Scardamalia and Bereiter (1994) have even describe this process as learners working collaboratively in solving a problem. It is because learners possess a sense of ownership when sharing their thoughts in resolving a matter together.

There is a distinct theoretical difference in which Piaget and Vygotsky view development and learning. The former opines that development fosters learning. However, Vygotsky is of the opinion that learning promotes development (Fowler, 2017).

From the constructivist perspective, it is crucial to have development of knowledge which is triggered by conflicts. There arises a need for cognition of learners to be modified. It could be achieved by reorganising and restructuring knowledge as an attempt to reach equilibrium due to the imbalance created by socio-cognitive conflicts (Cress and Kimmerle, 2008; Piaget 1977). As a result, there will be improvement in the learners' level of knowledge (Bell, Grossen \& Perret-Clerment, 1985).

\section{Methods \\ Participants}

There was a total of 19 students in this study. Ten of them were male students while nine of them were females. They were First Year Degree in Graphic Design students from a private university-college in Malaysia.

The participants formed four case study groups which were Groups 1, 2, 3 and 4. There were five participants in Groups 1, 2 and 4 while Group 3 comprised four members. The participants had mixed proficiency in English. Four of them obtained As, ten of them scored Bs while five of them obtained Cs for the English course they had completed in the previous semester of their studies. 


\section{Writing Tasks}

The participants performed three group-writing tasks which were a memorandum, a letter of complaint and an argumentative essay. The length of the letter and memorandum was 150 to 200 words each while the length of the essay was about 350 words. The memorandum task was pertaining to a manager reminding the staff to be punctual for work; the letter of complaint was regarding the dirty conditions in a college while the essay title was "Living in a small town is better than living in a city". The participants were taught the appropriate format, content, tone and language to be adopted for the respective writing tasks in their English classes prior to the collaborative writing sessions.

The participants formed their writing groups on their own. It was because they were comfortable in working with their group members for they had worked in those groups for their other assignments. Leaders were also appointed to facilitate the collaborative writing sessions. The participants needed three face-to-face sessions of collaborative writing to perform their writing tasks with each session lasting two hours.

In addition, the participants uploaded their written products in platforms created in Google Classroom. The appointed case study groups edited the work and provided online feedback on it. The participants were advised to provide positive comments and constructive criticisms for their friends. Furthermore, their instructor vetted through their feedback to check on the accuracy before they uploaded it in Google Classroom.

\section{Data Collection}

The face-to-face collaboration were video-taped in order to enable the instructor cum researcher to observe the sessions in detail. In addition, the participants were interviewed individually and produced individual diary entries after every collaborative session. They were used to increase understanding of the episodes which occurred and to gauge the impact of using Google Classroom in their collaboration when editing other' work.

The researcher observed the face-to-face collaboration closely. The production of observation notes enabled significant episodes which occurred during the sessions to be recorded in detail. The different research methods used such as observations, interviews and diary entries provided triangulation of data required in this study.

\section{Results/ Findings}

The researcher encouraged the participants to reflect on their collaborative experiences deeply. Furthermore, the researcher attempted to comprehend significant situations during the sessions from her own perspective. Therefore, both research questions formed for this study could be answered using the input from both researcher and participants. The findings from this study are divided into two categories which are namely, critical incidents identified and suggestions on improving collaborative writing and editing in a Google Classroom. 


\section{Research Question 1: What critical incidents are observed when collaborative writing and editing are used in a Google Classroom?}

There are two critical incidents observed during collaborative writing and editing. They are an increase of motivation and reduced anxiety level when receiving peer feedback on their writing.

\section{Increase of Motivation}

The researcher observed that the participants were motivated in performing their tasks. They had a strong sense of ownership towards their tasks and were excited in working with their group members compared to working together in the past. Additionally, their instructor did not have to remind them of the deadlines to follow when submitting their work.

Furthermore, the participants' enthusiasm was evident when they reminded one another to complete their tasks for both the composing and editing processes. Most of the participants were eager to receive their online feedback. They were constantly checking with their peers whether they had posted their feedback. Consequently, their peers were prompt in submitting it. The participants happily read the comments aloud to one another upon receiving them.

The participants' opinions gathered from the interviews and diary entries reflected their positive responses during the sessions. The comments ranged from "... friend check work to improve work ...", "... learn from fren how to write well ...", " ... not scared I make mistake becoz. my friend edit work ... can learn ...", "... good, ... read friend's comments ... know my mistake so can improve (-) ...", "... very proud friends say good essay (). ", "... so exciting can put writing online ... after that read comment ...", "... we feel happy to write ... receive comment also quickly ..."

The findings obtained from this study are similar with results collected from studies conducted by Haerazi and Irawan (2019) and Perkel (2020). According to the former, motivation is very crucial in students' writing practices. Furthermore, Perkel (2020) who conducted a study on synchronised editing performed during collaborative writing discovered the importance of creating a conducive learning environment for students. The results also highlighted that participants were positive towards placing their work online via Twitter for it was publicly accessible which made it possible for obtaining feedback from a wider group of co-authors compared to traditional face-to-face collaboration.

\section{Reduced Anxiety in Receiving Feedback}

The participants were observed to be relaxed and comfortable during their sessions. Their facial expressions and positive behaviour highlighted their enthusiasm towards their collaborative tasks.

Overall, they preferred receiving online peer feedback on their writing compared to face-to-face peer feedback. The participants explained that they did not feel intimidated at all receiving online feedback for they were given the leisure of time to accept and reflect on the comments. Their satisfaction of receiving online feedback was evident from their opinions obtained from the interviews and diary entries which were "... not so stress ... ok to show me mistake like that ...", "... can say no stress ... we know our friends check not other people ... 
only read when we ready $(-)$..." and "... hope can do like this more, more time given when write ... not so scared when essay checked by coursemates ... can read comment anytime ..."

Furthermore, they admitted they felt discomfort with face-to-face peer feedback because they felt humiliated when their mistakes were highlighted for they needed to "confront" their peers over them. The participants were contented with the online feedback because they did not directly feel embarrassed by negative comments provided on their writing due to a lack of face-to-face encounter. Consequently, they felt that their "face" were maintained and they felt dignified. Their opinions obtained through their interviews and diary entries were "... not too bad ... don't feel shy when friends checked ...", "My work not criticised ... can accept their comment ...", "... no need to feel ashamed ... friend consider our face and feelings ..."

\section{Research Question 2: What are recommendations of improving collaborative writing and} editing in a Google Classroom?

Both researcher and participants in this study provided some suggestions on how to improve future collaborative writing and editing sessions. They are providing shorter time allocation for tasks, giving roles for students to play and promoting participation through instructor's guidance.

\section{Shorter Time Allocation for Task Completion}

It was observed that all of the groups performed their collaborative writing and editing tasks successfully in this study. They were given a week to complete each task. Therefore, some of them posted their work very early before the deadlines while some sent their work just before the deadlines. Consequently, the peer editors had to constantly check with their friends whether they had submitted their work before they could start performing their tasks. Similarly, the writers had to constantly enquire their peer editors whether they had posted their comments. The situations created some unhappiness among the participants. Therefore, a number of the participants suggested having a shorter time for their collaborative work.

The participants' opinions obtained from their interviews and diary entries reflected their frustrations on being uncertain of when their friends had completed their work and they also highlighted the importance of having a clear time frame for their collaborative tasks. The comments were "... always have to check if work was done so difficult ...", "This session my friends submit early so can work early not like last time ...", "... one week too long ... dunno when can check ...", "Why not set shorter time to write? One week too long ...", "I think can write in a few days, ... not one week", "... write together can finish work faster ... we finish very fast ... then nothing to do (-) " and "Writing not so hard when write with group ... we always chit-chat after that ..."

\section{Provide Clear Roles to Increase Participation}

The participants suggested having clear roles for students when they collaborated with their group members. They felt strongly that it would help them to have a fair allocation of subtasks to perform and enabled them to play their roles confidently. It was observed during the collaborative sessions that not all of the group members were participating actively resulting in only a few of them attempting the tasks consistently. 
The participants expressed their frustrations of unequal participation and even provided suggestions during the interviews and from their diary entries on how to improve their collaboration. Their comments were "... same people do work ...", "Maybe get everyone active? Then ... better that way ...", "Actually I dun mind but is many people do work, better, right?", "I think ... give everyone something to do ...", "All participate, give everyone a role ... become more responsible ...", "... feel a bit unsure what to do ... tell each one what to do?" and "I suggest improve sessions ... make students know which roles to play - one do research, one write outline, then write ...."

According to Dillenbourg (2002), it is crucial to provide instructional scaffolding to assist collaborators. It is because learners may not experience potential advantages from collaborative work for successful results from team efforts are not autonomous. Therefore, preparation prior to collaboration must be given much emphasis.

\section{Guidance in Providing Feedback}

Another suggestion provided by both the researcher and the participants was preparing students to become peer editors. It was due to the lack of confidence the participants displayed when checking their friends' work resulting in them constantly checking with the researcher cum instructor on whether their comments were appropriate. Furthermore, the researcher had to help some of them to tone down on their feedback when it became too critical and not constructive to their friends.

It was evident from the information provided by the participants through their interviews and diary entries that some of them were uncertain on how to provide feedback on their friends' work. Consequently, they suggested preparing students for their peer editing tasks. Their opinions were "... not sure how to comment at first ...", "Ok after a while, we learn how to check friends' work ...", "... usually teacher check not us check ... now we know how to comment ...", "Maybe train us become like teacher in checking work?", "... good to learn how to comment ..." and "Prepare students ... like comment on work ..."

The suggestion of guiding students in their collaborative efforts concurred with recommendations provided in studies conducted by Olson et al (2017) and Bromme et al (2015). The former were of the opinion that system design implications and behavioural guidelines were crucial in ensuring success during collaborative writing. Furthermore, the latter emphasised on the need to pre-define and inform collaborators of regulations to follow in performing their tasks such as providing wiki articles and discussion pages.

\section{Conclusion}

The findings in this study revealed two critical incidents which occurred during collaboration and highlighted suggestions on improving future collaborative sessions. The former are an increase of student motivation and reduced student anxiety level while the latter are providing shorter time allocation for tasks, giving clear roles for students to play and promoting participation through instructor's guidance.

It can be concluded that the findings from this study have provided insights to instructors and students on the use of collaboration and Google Classroom in ESL lessons. 
Their uses should be promoted especially in writing classrooms and be refined in their implementation in order to increase their effectiveness.

\section{References}

Aulia, K., Afrianto, D., \& Mahdum, A. (2020). Students' acceptance of the use of Google Classroom as a platform in blended learning. Al-Ishlah: Jurnal Pendidikan, 12(1), 1-16.

Azhar, K. A., \& Iqbal, N. (2018). Effectiveness of Google classroom: Teachers' perceptions. Prizren Social Science Journal, 2(2), 52-66.

Bell, N., Grossen, M., \& Perret-Clermont, A.-N. (1985). Sociocognitive conflict and intellectual growth. New Directions for Child and Adolescent Development, 29, 41-54. doi: 10.1002 /cd.23219852905.

Bennett, N., \& Cass, A. (1988). The effects of group composition on group interactive processes and pupil understanding. British Educational Research Journal, 15(1), 1988.

Bromme, R., Hesse, F. W., \& Spada, H. (2005). Barriers and biases in computer-mediated knowledge communication - and how they may be overcome (Vol. 5), Springer.

Cantika S. D. M., \& Rezki, S. Q. (2020). The effectiveness of Google Classroom as English learning assistance. Jurnal Penelitian dan Pengabdian Kepada Masyarakat, 1(1), 4753.

Cress, U., \& Kimmerle, J. (2008). A systemic and cognitive view on collaborative knowledge building with wikis. International Journal of Computer-Supported Collaborative Learning, 3(2), 105-122. doi: 10.1007/s11412-007-9035-z.

Dillenbourg, P. (2002). Over-scripting CSCL: The risks of blending collaborative learning with instructional design. In P. A. Kirschner (Ed.), Three worlds of CSCL. Can we support CSCL? (pp. 61-91). Heerlen: Open Universiteit Nederland.

Dillenbourg, P., Järvelä, S., \& Fischer, F. (2009). The evolution of research on computersupported collaborative learning. In N. Balacheff, S. Ludvigsen, T. de Jong, A. Lazonder, \& S. Barnes (Eds.), Technology-enhanced learning (pp. 3-19). Dordrecht: Springer Netherlands. https://doi.org/10.1007/978-1-4020-9827-7_1.

Ede, L. S., \& Lunsford, A. (1990). Singular texts/plural authors: Perspectives on collaborative writing. SIU Press.

Ela N. L., \& Tatik M. (2020). The effectiveness of Google Classroom in teaching writing of recount text for senior high schools. Journal of Languages and Language Teaching, 8(4), 348-359.

Fowler, R. C. (2017). Reframing the Debate About the Relationship Between Learning and Development: An Effort to Resolve Dilemmas and Re-establish Dialogue in a Fractured Field. Early Childhood Education Journal, 45(2), 155-162.

Haerazi, H., \& Irawan, L. A. (2019). Practising genre-based language teaching model to improve students' achievement of writing skills. IJELTAL (Indonesian Journal of English Language Teaching and Applied Linguistics), 4(1), 9-18. doi: 10.21093/ijeltal.v4i1.246

Hafner, C. A., \& Yu, C. (2020). Language socialisation in digitally mediated collaborative writing: Evidence from disciplinary peer and teacher feedback. RELC Journal, 51(1), 1432.

Heggart, K. R., \& Yoo, J. (2018). Getting the Most from Google Classroom: A Pedagogical Framework for Tertiary Educators. Australian Journal of Teacher Education, 43(3), 140-153.

Hernández, R. (2012). Collaborative learning: Increasing students' engagement outside the classroom. US-China Education Review, A 9, 804-812. 
Iftakhar, S. (2016). Google Classroom: What Works and How?. Journal of Education and Social Science, 3, 12-18.

Jakkaew, P., \& Hemrungrote, S. (2017). The use of UTAUT2 model for understanding student perceptions using Google classroom: A case study of introduction to information technology course. 2017 International Conference on Digital Arts, Media and Technology (ICDAMT), 205-209. https://doi.org/10.1109/ICDAMT.2017.7904962.

Jeya, A. K., \& Brandford, B. (2019). Google Classroom for mobile learning in higher education: Modelling the initial perceptions of students. Education and Information Technologies, 24(2),1793-1817.

Jones, R. W. (2007). Learning and teaching in small groups: Characteristics, benefits, problems, and approaches. Anaesthesia and intensive care, 35(4), 587.

Khalil, Z. M. (2018). EFL Students' Perceptions towards using Google Docs and Google Classroom as online collaborative tools in learning grammar. Applied Linguistics Research Journal, 2, 33-48.

Liao, B. (2020). Language-related episodes in learner-native speaker collaborative writing interaction. Electronic Journal of Foreign Language Teaching, 17, 135-153.

Olson, J. S., Wang, D., Olson, G. M., \& Zhang J. W. (2017). How people write together now: Beginning the investigation with advanced undergraduates in a project course. ACM Transactions on Computer-Human Interaction (TOCHI), 24(1), 1-40.

Perkel, J. M. (2020). Synchronised editing: The future of collaborative writing. Nature, 580(7801), 154-155.

Piaget, J. (1977). Problems of equilibration. In M. H. Appel \& L. S. Goldberg (Eds.), Topics in Cognitive Development (pp. 3-13). Springer US.

Ramadhani, R., Umam, R., Abdurrahman, A., \& Syazali, M. (2019). The effect of flippedproblem based learning model integrated with LMS-Google Classroom for senior high school students. Journal for the Education of Gifted Young Scientists, 7(2), 137-158.

Scardamalia, M., \& Bereiter, C. (1994). Computer support for knowledge-building communities. The Journal of the Learning Sciences, 3(3), 265-283. doi.: 10.1207/s15327809jls0303_3.

So, H.-J., Seah, L. H., \& Toh-Heng, H. L. (2010). Designing collaborative knowledge building environments accessible to all learners: Impacts and design challenges. Computers \& Education, 54(2), 479-490. doi: 10.1016/j.compedu.2009.08.031

Storch, N. (2005). Collaborative writing: Product, process, and students' reflections. Journal of Second Language Writing, 14(3), 153-173.

Sun, Y. C., \& Chang, Y. J. (2012). Blogging to learn: Becoming EFL academic writers through collaborative dialogues. Language Learning \& Technology, 16(1), 43-61. Retrieved from http://lt.msu.edu/issues/february2012/sunchang.pdf

Swain, M. (2000). The output hypothesis and beyond: Mediating acquisition through collaborative dialogue. In J. P. Lantolf (Ed.), Sociocultural theory and second language learning (pp. 97-114). Oxford University Press.

Vygotsky, L. S. (1986). Thought and language in a revised edition. The MIT Press.

Waggoner, M., Chinn, C., Yi, H., \& Anderson, R. C. (1995). Collaborative reasoning about stories. Language Arts, 72, 582-589.

Wang, S., \& Vasquez, C. (2012). Web 2.0 and second language learning: What does the research tell us? CALICO Journal, 29(3), 412-430. 
Yang, L. (2014). Examining the mediational means in collaborative writing: Case studies of undergraduate ESL students in business courses. Journal of Second Language Writing, 23, 74-89.

Yim, S., \& Warschauer, M. (2017). Web-based collaborative writing in L2 contexts: Methodological insights from text mining. Language Learning \& Technology, 21(1), 146-165. Retrieved from http://It.msu.edu/issues/february2017/yimwarschauer.pdf 